\title{
Impact of Teachers' Gender and Self-Efficacy on End of Year Elementary Students Mathematics Assessments in Rural South Texas Schools
}

\author{
Kristina J Gonzalez, Ed.D. \\ Premont Independent School District \\ Lori Kupczynski, Ed.D. \\ University of St. Augustine for Health Sciences \\ Kelly Hall, Ph.D. \\ Texas A\&M University-Kingsville \\ Don Jones, Ed.D. \\ Texas A\&M University-Kingsville
}

Received: June 7, 2019 Accepted: August 6, 2019 Published: August 1, 2019

doi:10.5296/jse.v9i3.15126 URL: https://doi.org/10.5296/jse.v9i3.15126

\begin{abstract}
The purposes of this study were to compare grade 3 math achievement based on gender of teacher and to investigate if teacher self-efficacy predicts grade 3 math achievement. This study was framed around the concept of teacher self-efficacy. An independent sample $t$-test revealed that teacher gender made a substantive difference in the outcome of students who met grade level standards for grade 32018 STAAR math. A bivariate linear regression showed that self-efficacy for teaching mathematics at the elementary level did not predict the proportion of students who met grade level standards for grade 32018 STAAR math. Results indicated that neither gender nor self-efficacy of rural south Texas elementary teachers significantly impact the proportions of students who met grade level standards.
\end{abstract}

Keywords: mathematics achievement, rural education math achievement 


\section{Introduction}

Elementary teachers throughout the state of Texas who hold a generalist teaching certification are able to teach any subject spanning across early childhood education up to sixth grade. However, sometimes teachers are assigned to a core subject area, such as math, in which they may lack the efficacy needed to educate students at an essential level that is vital for students' long-term success (Gonzalez \& Maxwell, 2018). Research conducted by Gonzalez-DeHass, Furner, Vásquez-Colina and Morris (2017), determined that self-efficacy was a predictor of teachers' math anxiety. Additionally, according to Looney, Perry, and Steck (2017), preservice teachers have high anxiety for math and when it comes to actually completing math problems, they have a lower self- efficacy.

The purposes of this study were to compare grade 3 math achievement based on gender of teacher and to investigate if teacher self-efficacy predicts grade 3 math achievement.

\section{Review of Literature}

There are various ways to determine and measure academic achievement. There are many factors that impact differences in math achievement within the United States and among other nations. Research shows that opportunities to learn mathematics is the main element of success (Hadar, 2017).

Teacher experience and knowledge, according to Chapman (2015), is essential for students to be actively engaged in real-life, meaningful, and applicable math practices in the classroom. This allows students to create a deeper comprehension of math concepts. Additionally, preservice teacher education and on-going professional development are factors that may contribute to how effective an elementary math teacher may be and the impact they have on their student's achievement in math content.

\subsection{Preservice Teachers}

According to Hourigan and O'Donoghue (2015), there are many qualified and preservice elementary teachers that lack mathematics subject matter knowledge (MSMK) for teaching. In the past, a 'minimalist' view was the norm. This meant that someone had adequate knowledge of math if one was simply able to perform the math problems that were presented in the curriculum (Hourigan \& O'Donoghue, 2015). This notion, however, has been discarded since standards have become increasingly rigorous at the elementary level. In order for educators to show improvement in classrooms, there needs to an emphasis on the way teacher educators present information on math content and teaching to their preservice educators (Castro-Superfine \& Li, 2014). Olanoff, Jane-Jane, \& Tobias (2014) state that the need for educator preparation math classes for preservice teachers needs to include other concepts such as analyzing the way students think, focus on traditional and non-traditional standard algorithms for solving problems, emphasizing concepts that may affect math operations such as the function of units, and address several ideas for preservice teachers to develop one concept. Furthermore, preservice teachers should be able to determine if students' mistakes are random or if errors are based on the systemic nature of students' understanding and thought process (Castro-Superfine \& Li, 2014). 


\subsection{Professional Development}

According to Polly, Neale, \& Pugalee (2014), actively participating in ongoing professional development can lead to a substantial increase in math knowledge and new knowledge on how to teach the content. Further research conducted by Polly et al. (2015) shows an increase in teachers' math knowledge for teaching (MKT) including an essential connection between MKT post-project scores and student achievement on math content assessments. Thus, this specific professional development showed teacher effectiveness impacts student achievement in a positive way. Professional development, which systematically focused on instruction, math concepts, and unpacking content standards, led to an increase in the mathematical knowledge of teachers, and in turn was correlated to gains in student learning (Polly et al., 2015). Findings provide confirmation that student-centered professional development program for teachers, which highlighted student-centered math instruction and best practices math curriculum, led to a greater use of student-centered strategies in classrooms (Polly et al., 2015).

\subsection{Gender and Math Achievement}

Gender is the socially formed characteristics of males and females. These individualities can include norms, roles, and relationships of and between groups of women and men. It can differ from society to society or from culture to culture and can be changed. Gender differences in math achievement continues to exist in some countries, including the United States, (Ziegler et al., 2014) and these differences continue to capture the interest of many stakeholders, including educators and policymakers (Reilly, Neumann, \& Andrews, 2015). According to research conducted by Cheema and Galluzzo, there is evidence to support a small, yet significant gender achievement gap in mathematics (2013). Addressing this gap in achievement between male and female students is of a concern for state education policymakers and curriculum writers (Winters, Haight, Swaim, \& Pickering, 2013). School districts may begin to question whether the curriculum they are using is causing such a gap. The gender gap in math performance, as researched by Cheema and Galluzzo, is seen at the basic level of analysis when a small number of variables are present (2013). This gap, however, disappears at a higher-level analysis that take into account a rather large number of predictors of math performance (Cheema \& Galluzzo, 2013). Furthermore, teachers tend to underestimate girls' math performance in relation to boys who perform and behave similarly. This underrating appears to significantly facilitate the development of gender performance gaps in elementary schools (Robinson-Cimpian, Theule-Lubienski, Ganley, \& Copur-Gencturk, 2014).

Elementary schools across many countries have documented an imbalanced distribution of male and female teachers. Female teachers represent a huge majority and male teachers represent the minority (Burusic, Babarovic, \& Seric, 2012). According to Helbig (2012), current research about math differences between girls and boys are the result of the lack of male teachers. An overrepresentation of female teachers is often a predictor for the fact that girls usually perform better than their male peers at schools in the United States and just about all other countries of the western world. Also, one reason of gender differences in students' math performance is related to the dynamics of student-teacher gender interaction, 
particularly, to teacher-student gender combination (Burusic, et al., 2012). Winters et al., (2013) stated that one consideration to decrease the gender achievement gap is to place students with teachers of the same gender. For instance, in mathematics classes place male students with male teachers and female students with female teachers. Assigning students to the same gender teacher could perhaps increase a student's achievement because the teacher can serve as a role model and be more interested into thinking more positive about the student's abilities and potential (Winters et al., 2013). Another possibility concerning a teachers' insight to gender differences in math performance is that it may be influenced by gender differences in a students' behavior (Robinson-Cimpian et al., 2014).

\subsubsection{Gender and Behavior}

According to Robinson-Cimpian et al. (2014), girls that are seen as more competent in math could possibly lie in differences between teachers' views of boys' and girls' behavior and the effort they put into their work. Tianlan, Xun and Barnard-Brak, (2015) found that boys' have an advantage in the acceleration of growth in mathematics. Robinson-Cimpian et al. (2014) state that either fostering awareness or reducing the inclination for teachers to rate boys as more advanced than girls who perform and behave equally may help lessen the gender achievement gap in math. Female teachers, compared to male teachers, have reported significantly less close relationships with boys (Spilt, Koomen, \& Jak, 2012), thus swaying them to be more persuaded to view female students as better performing.

\subsection{Teacher Self-Efficacy}

A teacher's awareness of self-efficacy is an important element to having a successful classroom and is a meaningful characteristic for a teacher to have. This sense of self-efficacy is also connected with the quality of instruction teachers yield and as a result, student achievement outcomes (Miller, Ramirez, \& Murdock, 2017). Teacher self-efficacy is the degree of self-confidence a teacher has in their capability to stimulate and encourage a student's performance. It represents the belief that they can foster students' education, despite demanding and challenging circumstances (Künsting, Neuber \& Lipowsky, 2016). Teachers who have high confidence (greater self-efficacy) in their abilities will garner better outcomes in student learning. Teachers' self-efficacy impacts students' educational results such as motivation, achievement, and success (Scherer, Jansen, Nilsen, Areepattamannil, \& Marsh, 2016).

Some researchers have begun to realize the significance of self-efficacy as an indicator of teaching math effectively (Katz \& Stupel, 2016). Educators that have high self-efficacy beliefs are more inclined to incorporate new ideas in curriculum, have less discipline problems resulting from respectable classroom management, and have positive relationships with colleagues and parents (Miller et al., 2017). Knowing and understanding math content and personal teaching self-efficacy are positively related. There is no significant relationship between math content knowledge and expected outcomes of math performance (Newton, Leonard, Evans \& Eastburn, 2012). In a survey conducted by Chen, McCray, Adams, and Leow, results showed that teachers' self-confidence in their capability to teach pre-school math is superior to their assurance in their own ability to do math (2014). Furthermore, 
researchers found an insignificant, but positive relationship amongst teacher self-efficacy and math achievement across second and third grade students (Campbell et al., 2014). When examining the relationships between teacher self-efficacy and math achievement separately for both grade levels, meaningful relationships were found for second-graders only (Campbell et al., 2014). Zee and Koomen (2016) state that a because students' math achievement does not change across years as a result of teacher self-efficacy, other characteristics, such as math content knowledge, skills, and experience can possibly attribute to this achievement. These characteristics may have a greater impact on a students' math performance and achievement than a teachers' sense of self-efficacy. The inconsistency between "professional" and "personal" math suggests that elementary teachers believe they can teach math rather well, even though they do not feel they are good at their math skills (Chen et al., 2014). Hoy and Tarter (2011) propose that other characteristics such as "passion" and "resilience" must be regarded in order to foresee the effectiveness of a teacher and their ability to continue in their math teaching efforts. Additionally, a teachers' self-efficacy has been identified as a way to influence the kind of relationship a teacher may have with their students and the nature of the classroom atmosphere they offer; both of which can impact the results of students' achievements (Miller et al., 2017).

The support a teacher offers, mainly academic support, that clearly focuses on students' coursework, may essentially aid students' efficacy in learning (Rosenfeld, Richman, \& Bowen, 2000). Lazarides, Buchholz, and Rubach defined three characteristics of teachers' senses of self- efficacy: self-efficacy for teaching, self-efficacy for classroom organization and management, and self-efficacy for student engagement (2018). Liu et al. (2018) found that teacher self-efficacy supported the relationship of teacher assistance to math interest. For instance, when a math teacher occupies themselves in their students who do not perform well and attend to them by honing in on how they are solving problems, the students will be less embarrassed from making mistakes, have more assurance in their math abilities, and develop a greater awareness of control over their learning (Liu et al., 2018). According to Lazarides et al. (2018), teacher self-efficacy of classroom organization and management is their sense of his or her capability to effectively perform classroom management responsibilities. Moreover, there has been a significant relationship between teachers' self-efficacy of classroom management and the ability to master the goals they set for their classroom. According to Aldridge, Afari, and Fraser, (2013) when students feel that they are tended to as an individual and person, rather than just a student, they might be more inclined to share in more constructive and encouraging communication with the teacher. When this occurs, students can discover, discuss, learn, and engage more confidently in math class rather than have a sense of weakness and frustration. McGeown et al. (2014) recommend that teachers who work with and teach and high school students should reflect on the influence of teacher self-efficacy characteristics as a potential method to enhance academic motivation and drive.

\section{Methodology}

A quantitative research method was the approach taken to study the impact of teachers' gender and self-efficacy on end of year elementary students' mathematics assessments in rural South Texas schools. This non-experimental research was ex post facto. Data were 
collected by a survey from a cross-section of teachers and from DITSA. Teachers answered questions from the Mathematics Teacher Efficacy Belief Instrument (MTEBI) through Survey Monkey. Once the survey was complete, data were entered into IBM SPSS along with data for end of year math assessments acquired from the DITSA site.

\subsection{Variables}

The two independent variables for this study included teacher gender and teacher self-efficacy. The dependent variable was student achievement operationally defined as the proportion of students who met standards on grade 32018 STAAR math. The numerical data in this study was collected from elementary teachers who teach in schools located in a rural region in the southern half of Texas. The teachers who volunteered took the Mathematics Teacher Efficacy Belief Instrument (MTEBI). Data from $3^{\text {rd }}$ grade STAAR math scores were collected to measure student achievement, the dependent variable.

\subsection{Population and Sample}

Elementary mathematics teachers in rural Texas schools, located in the southern half region of the state, served as the population for this study. There were 16 school districts identified as rural schools in this specific region. These districts were classified as rural schools because of the following: student enrollment was between 300 and the school had a student growth rate of less than 20 percent over the past 5 years or the school had less than 300 students enrolled in the school. Surveys were sent to teachers in seven of these districts $(N=75)$. The sample for this research was considered voluntary (McMillan \& Schumacher, 2010). Teachers participated in the survey in the spring of 2019. The survey included questions on gender and teachers' self-efficacy. Additionally, student math assessment data from grade 3 of the same rural South Texas schools, were accessed; data from $3^{\text {rd }}$ grade STAAR mathematics scores from the 2017-2018 school year were collected from the DITSA site.

\subsection{Instrumentation}

This study utilized the Mathematics Teaching Efficacy Belief Instrument (MTEBI). The MTEBI was from the adaptation of the Science Teaching Efficacy Belief Instrument STEBI-B (Enochs, Smith, \& Huinker, 2000). This instrument measures mathematics efficacy beliefs. The MTEBI contains 21 items; 13 items on the self-efficacy (SE) subscale and eight items on the Mathematics Teaching Outcome Expectancy (MTOE) subscale (Enochs et al., 2000).

Reliability shows the accuracy of test scores, which also reflects the consistency of test results across testing conditions. Validity refers to the extent to which test scores can be interpreted as indicators of what the test is intended to measure. Reliability analysis for the MTEBI produced an alpha coefficient of internal consistency (Cronbach's alpha) of .88 for the PMTE scale and an alpha coefficient of .77 for the MTOE scale (Enochs et al., 2000). Confirmatory factor analysis indicated that the two scales (PMTE and MTOE) are independent, adding to the construct validity of the MTEBI (Enochs et al., 2000). The MTEBI appears to be a valid and reliable assessment of mathematics teaching self-efficacy and outcome expectancy (Enochs et al., 2000). 


\subsection{Data Collection}

An email was sent to 16 rural elementary schools located in the southern half region of Texas. The email requested approval from the superintendents of these schools to send out an email to teachers. The second email requested elementary teacher's participation in the survey (MTEBI), a link for the survey was attached. The collection phase lasted from January 2019 to the end of February 2019. Numerical data from the MTEBI was downloaded from Survey Monkey as an excel file and imported into IBM SPSS. End of year 2018 STAAR mathematics assessment data for grade 3 students was obtained from the DITSA site. Data Interaction for Texas Student Assessments public, analytic portal allows all users to view grade level results across all Texas K-12 public and charter organizations (Texas Assessment Management System, 2017). STAAR data from rural elementary schools located in the southern half region of Texas were accessed.

\section{Results}

\subsection{Research Question 1}

Research question 1 examined differences of grade 3 elementary school students who met grade level standards on the STAAR based on whether they have had male or female elementary school teachers. Results indicated about one-half of grade 3 students $(M=.46 ; S D$ $=.20$ ) who had both male and female elementary school teachers met grade level standards on the STAAR. To compare if there was a difference in the mean proportion of grade 3 elementary school students who met grade level standards on the STAAR based on gender, an independent sample $t$-test was calculated. Though means were substantively different between male $(M=.59 ; S D=.23)$ and female $(M=.45 ; S D=.20)$ teachers, differences were not statistically significant, $t(21)=.97, p=.35, d=.72$. Cohen's $d$ indicated a medium to large effect size. The large magnitude may be a result of the substantive difference in the mean proportions between male and female teachers.

\subsection{Research Question 2}

Research question 2 investigated if teacher self-efficacy can predict the proportion of grade 3 elementary school students who met grade level standards on the STAAR.

Bivariate linear regression was used to evaluate the null hypothesis that self-efficacy cannot predict the proportion of grade 3 elementary school students who met grade level standards on the STAAR. Analysis indicated that self-efficacy $(M=4.06 ; S D=.40)$ cannot predict the proportion of grade 3 elementary school students who met grade level standards on the STAAR, $F(1,21)=.15, p=.70$. The proportion of students who met grade level standards on STAAR is represented by $M=.46 ; S D=.20$.

\section{Summary, Conclusions and Recommendations}

Research regarding teacher gender in relation to student achievement has shown varying connections (Burusic et al., 2012; Robinson-Cimpian et al., 2014). In elementary schools, for instance, female teachers produce students with higher math achievement than their male co-workers (Manzar-Abbas \& Lu, 2015; Wood, 2012). This could possibly stem from male 
teachers being underrepresented in elementary schools (Helbig, 2012). Findings from this study showed that the mean proportion of students who met grade level standards was slightly higher for male teachers $(M=.59 ; S D=.23)$ than female teachers $(M=.45 ; S D$ $=.20)$; however, differences were not significant $(p=.35)$. Additionally, this study discovered that male teachers are greatly underrepresented in rural South Texas elementary schools. This dispels the notion that mathematics in general, is associated with manliness (Damarin \& Erchick 2010).

As evidenced by research, self-efficacy plays a vital role in math achievement (Jungert \& Andersson, 2013). In addition, significant relationships have been found between self-efficacy and students' academic achievement across different grade levels spanning from elementary through high school (De Feyter, Caers, Vigna, \& Berings, 2012; Jungert \& Andersson, 2013; Katz \& Stupel, 2016; Scherer et al., 2016). However, specifically for grade 3 , researchers have found insignificant relations between teacher self-efficacy and math achievement (Campbell et al., 2014). Likewise, in this study, self-efficacy did not predict grade 3 student achievement $(p=.70)$.

Contrary to research by Campbell et al. (2014), this study indicated that gender and self-efficacy do not predict the outcome of the proportion of students who met grade level standards, it is important to explore whether a larger sample would yield the same results.

State accountability requirements, in accordance with TAC, put increased pressure on teachers to get students to continually show improvement and perform at grade level (TEA, 2018). Likewise, administrators have the challenging task to assign teachers to areas in which they will be successful and attain these results set forth by the state. Additionally, according to Chen et al. (2014), teachers have different degrees of efficacy in their math teaching abilities which can be traced to their education and training. It is important to note that educator preparation programs greatly influence teacher self-efficacy when it comes to teaching in an assigned grade level and subject. This study contributed evidence that rural elementary schools, located in the southern half region of Texas, employ teachers that are efficacious in teaching mathematics; which may be attributed to the teacher preparation program they attended.

Student achievement, at any grade level, is important for continued growth and knowledge for the larger society. Unfortunately, from the moment students enter public school, they are constantly burdened with having to take assessments to determine their knowledge in a particular subject. Knowing that they have a teacher that is efficacious in the subject they teach gives students, parents, and administrators a sense of assurance that they will have the best opportunity to meet the requirements set forth by the state. This study determined that neither teachers' gender nor self-efficacy, from elementary schools in a region in the southern half of Texas, impact the proportion of students who meet grade level standards for students in grade 3 .

\section{References}

Burusic, J., Babarovic, T., \& Seric, M. (2012). Differences in elementary school achievement between girls and boys: Does the teacher gender play a role? European Journal of Psychology of Education, 27(4), 523-538. https://doi.org/10.1007/s10212-011-0093-2 


\section{Macrothink}

Campbell, P. F., Nishio, M., Smith, T. M., Clark, L. M., Conant, D. L., Rust, A. H., \& Youyoung, C. (2014). The relationship between teachers' mathematical content and pedagogical knowledge, teachers' perceptions, and student achievement. Journal for Research in $\quad$ Mathematics 419-459. https://doi.org/10.5951/jresematheduc.45.4.0419

Castro-Superfine, A., \& Li, W. (2014). Exploring the mathematical knowledge needed for teaching teachers. Journal of Teacher Education, 65(4), 303-314. https://doi.org/10.1177/0022487114534265

Cc Aldridge, J. M., Afari, E., \& Fraser, B. J. (2013). Influence of teacher support and personal relevance on academic self-efficacy and enjoyment of mathematics lessons: A structural equation modeling approach. Alberta Journal of Educational Research, 58, 614-633.

Chapman, O. (2015). Reflective awareness in mathematics teachers' learning and teaching. Eurasia Journal of Mathematics, Science \& Technology Education, 11(2), 313-324. https://doi.org/10.12973/eurasia.2015.1334a

Cheema, J. R., \& Galluzzo, G. (2013). Analyzing the gender gap in math achievement: evidence from a large-scale US sample. Research in Education, 90(1), 98-112. https://doi.org/10.7227/RIE.90.1.7

Chen, J., McCray, J., Adams, M., \& Leow, C. (2014). A survey study of early childhood teachers' beliefs and confidence about teaching early math. Early Childhood Education Journal, 42(6), 367-377. https://doi.org/10.1007/s10643-013-0619-0

Damarin, S., and Erchick, D. B., 2010. Toward clarifying the meanings of gender in mathematics education research. Journal for Research in Mathematics Education, 41(4), 310-323.

De Feyter, T., Caers, R., Vigna, C., \& Berings, D. (2012). Unraveling the impact of the Big Five personality traits on academic performance: The moderating and mediating effects of self efficacy and academic motivation. Learning \& Individual Differences, 22(4), 439-448. https://doi.org/10.1016/j.lindif.2012.03.013

Enochs, L. G., Smith, P. L., \& Huinker, D. (2000). Establishing factorial validity of the mathematics teaching efficacy beliefs instrument. School Science \& Mathematics, 100(4), 194. https://doi.org/10.1111/j.1949-8594.2000.tb17256.x

Gonzalez, K., \& Maxwell, G. (2018). Mathematics teachers' efficacy, experience, certification and their impact on student achievement. Journal of Instructional Pedagogies, $21(1), 2-4$.

Gonzalez-DeHass, A. R., Furner, J. M., Vásquez-Colina, M. D., \& Morris, J. D. (2017). Pre service elementary teachers' achievement goals and their relationship to math anxiety. Learning \& Individual Differences, 6040-45. https://doi.org/10.1016/j.lindif.2017.10.002

Hadar, L. L. (2017). Opportunities to learn: Mathematics textbooks and students'

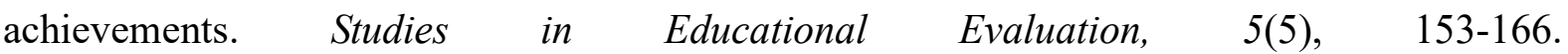


https://doi.org/10.1016/j.stueduc.2017.10.002

Helbig, M. (2012). Boys do not benefit from male teachers in their reading and mathematics skills: Empirical evidence from 21 European Union and OECD countries. British Journal of Sociology of Education, 33(5), 661-677. https://doi.org/10.1080/01425692.2012.674782

Hourigan, M., \& O'Donoghue, J. (2015). Addressing prospective elementary teachers' mathematics subject matter knowledge through action research. International Journal of Mathematical Education In Science \& Technology, 46(1), 56-75. https://doi.org/10.1080/0020739X.2014.936977

Hoy, W. K., \&Tarter, C. J. (2011). Positive psychology and educational administration: An optimistic research agenda. Education Administration Quarterly 47(3), 427-45. https://doi.org/10.1177/0013161X10396930

Jungert, T., \& Andersson, U. (2013). Self-efficacy beliefs in mathematics, native language literacy, and foreign language amongst boys and girls with and without mathematics difficulties. Scandinavian Journal of Educational Research, 57(1), 1-15. https://doi.org/10.1080/00313831.2011.621140

Katz, S., \& Stupel, M. (2016). Enhancing elementary-school mathematics teachers' efficacy beliefs: A qualitative action research. International Journal of Mathematical Education in Science \& Technology, 47(3), 421-439. https://doi.org/10.1080/0020739X.2015.1080314

Kim, Y. (2017). Does autonomy over teacher hiring affect student math and science achievement? Education Economics, 25(6), 562-574. https://doi.org/10.1080/09645292.2017.1328044

Künsting, J., Neuber, V., \& Lipowsky, F. (2016). Teacher self-efficacy as a long-term predictor of instructional quality in the classroom. European Journal of Psychology of Education, 31(3), 299-322. https://doi.org/10.1007/s10212-015-0272-7

Lazarides, R., Buchholz, J., \& Rubach, C. (2018). Teacher enthusiasm and self-efficacy, student-perceived mastery goal orientation, and student motivation in mathematics classrooms. Teaching \& Teacher Education, 6(9),1-10. dhttps://doi.org/10.1016/j.tate.2017.08.017

Liu, R., Zhen, R., Ding, Y., Liu, Y., Wang, J., Jiang, R., \& Xu, L. (2018). Teacher support and math engagement: Roles of academic self-efficacy and positive emotions. Educational Psychology, 38(1), 3-16. https://doi.org/10.1080/01443410.2017.1359238

Looney, L., Perry, D., \& Steck, A. (2017). Turning negatives into positives: The role of an instructional math courses on preservice teachers' math beliefs. Education, 138(1), 27-40.

Manzar-Abbas, S. S. \& Lu, L. (2015). Self-efficacy beliefs of Chinese primary school teachers. Pakistan Journal of Psychological Research, 30(02), 289-303.

McGeown, S. P., Putwain, D., Geijer Simpson, E., Boffey, E., Markham, J., \& Vince, A. (2014). Predictors of adolescents' academic motivation: Personality, self-efficacy and 
adolescents' characteristics. Learning \& Individual Differences, 32278-286. https://doi.org/10.1016/j.lindif.2014.03.022

McMillan, J. H., \& Schumacher, S. (2010). Research in education: Evidence-based inquiry (7th ed.). Boston: Pearson.

Miller, A. D., Ramirez, E. M., \& Murdock, T. B. (2017). The influence of teachers' self-efficacy on perceptions: Perceived teacher competence and respect and student effort and achievement. Teaching \& Teacher Education, 6(4),260-269. https://doi.org/10.1016/j.tate.2017.02.008

Newton, K. J., Leonard, J., Evans, B. R., \& Eastburn, J. A. (2012). Preservice elementary teachers' mathematics content knowledge and teacher efficacy. School Science \& Mathematics, 112(5), 289-299. https://doi.org/10.1111/j.1949-8594.2012.00145.x

Olanoff, D., Jane-Jane, L., \& Tobias, J. M. (2014). Mathematical content knowledge for teaching elementary mathematics: A focus on fractions. Mathematics Enthusiast, 11(2), 267-310.

Polly, D., McGee, J., Wang, C., Martin, C., Lambert, R., \& Pugalee, D. K. (2015). Linking professional development, teacher outcomes, and student achievement: The case of a learner-centered mathematics program for elementary school teachers. International Journal of Educational Research, 7226-37. https://doi.org/10.1016/j.ijer.2015.04.002

Polly, D., McGee, J., Wang, C., Martin, C., Lambert, R., \& Pugalee, D. K. (2015). Linking professional development, teacher outcomes, and student achievement: The case of a learner-centered mathematics program for elementary school teachers. International Journal of Educational Research, 7226-37. https://doi.org/10.1016/j.ijer.2015.04.002

Polly, D., Neale, H., \& Pugalee, D. (2014). How does ongoing task-focused mathematics professional development influence elementary school teachers' knowledge, beliefs and enacted pedagogies? Early Childhood Education Journal, 42(1), 1-10. https://doi.org/10.1007/s10643-013-0585-6

Reilly, D., Neumann, D. L., \& Andrews, G. (2015). Sex differences in mathematics and science achievement: A meta-analysis of national assessment of educational progress assessments. Journal of Educational Psychology, 107(3), 645-662. https://doi.org/10.1037/edu0000012

Robinson-Cimpian, J. P., Theule-Lubienski, S., Ganley, C. M., \& Copur-Gencturk, Y. (2014). Teachers' perceptions of students' mathematics proficiency may exacerbate early gender gaps in achievement. Developmental Psychology, 50(4), 1262-1281. https://doi.org/10.1037/a0035073

Rosenfeld, L. B., Richman, J. M., \& Bowen, G. L. (2000). Social support networks and school outcomes: The centrality of the teacher. Child and Adolescent Social Work Journal, 17, 205-226. https://doi.org/10.1023/A:1007535930286

Scherer, R., Jansen, M., Nilsen, T., Areepattamannil, S., \& Marsh, H. W. (2016). The quest 
for comparability: studying the invariance of the teachers' sense of self-efficacy (TSES) measure across countries. PLOS ONE, $11(3), \quad 1-29$. https://doi.org/10.1371/journal.pone.0150829

Spilt, J. L., Koomen, H. M., \& Jak, S. (2012). Are boys better off with male and girls with female teachers? A multilevel investigation of measurement invariance and gender match in teacher-student relationship quality. Journal of School Psychology, 50(3), 363-378. https://doi.org/10.1016/j.jsp.2011.12.002

Texas Assessment Management System (2017). Retrieved from https://www.texasassessment.com/assessments/

Texas Education Agency. (2018). Accountability. Retrieved from https://tea.texas.gov/Student_Testing_and_Accountability/Accountability/Accountability

Tianlan, W., Xun, L., \& Barnard-Brak, L. (2015). Gender differences in mathematics and reading trajectories among children from kindergarten to eighth grade. Research in Education, 93(1), 77-89. https://doi.org/10.7227/RIE.0015

Winters, M. A., Haight, R. C., Swaim, T. T., \& Pickering, K. A. (2013). The effect of same-gender teacher assignment on student achievement in the elementary and secondary grades: Evidence from panel data. Economics of Education Review, 34, 69-75. https://doi.org/10.1016/j.econedurev.2013.01.007

Wood, Y. D. (2012). Teacher perceptions of gender-based differences among elementary school teachers. International Electronic Journal of Elementary Education, 4(2), 317-345.

Zee, M., \& Koomen, H. M. (2016). Teacher self-sfficacy and its effects on classroom processes, student academic adjustment, and teacher well-being: A synthesis of 40 years of research. Review of Educational Research, (86), 981-1015. https://doi.org/10.3102/0034654315626801

Ziegler, A., Stoeger, H., Harder, B., Park, K., Portešová, Š., \& Porath, M. (2014). Gender differences in mathematics and science: The role of the actiotope in determining individuals' achievements and confidence in their own abilities. High Ability Studies, 25(1), 35-51. https://doi.org/10.1080/13598139.2014.916092

\section{Copyright Disclaimer}

Copyright for this article is retained by the author(s), with first publication rights granted to the journal.

This is an open-access article distributed under the terms and conditions of the Creative Commons Attribution license (http://creativecommons.org/licenses/by/3.0/). 